\title{
PENERAPAN METODE INDEX CARD MATCH UNTUK MENINGKATKAN MINAT DAN PRESTASI BELAJAR EKONOMI PESERTA DIDIK PADA MATERI POKOK AKUNTANSI SEBAGAI SISTEM INFORMASI DI KELAS XI SMA NEGERI 1 ANGKOLA SELATAN TAHUN PELAJARAN 2016 - 2017
}

\author{
(1)Mardiana Nasution dan (2)Uli Anto Hutagalung \\ ${ }^{(1)}$ Mahasiswa FKIP Universitas Muhammadiyah Tapanuli Selatan \\ ${ }^{(2)}$ Dosen FKIP Univeristas Muhammadiyah Tapanuli Selatan
}

\begin{abstract}
Abstrak
Dalam penelitian ini penulis menggunakan metode penelitian secara deskriftif yaitu dengan membuat suatu hasil-hasil penelitian secara sistematis dan terinci. Alat pengumpulan data yang penulis lakukan adalah dengan menggunakan angket. Waktu penelitian dilaksanakan \pm 3 ( tiga) bulan. Populasi dalam penelitian ini adalah seluruh kelas XI dan sampelnya adalah kelas XI-1. Instrumen yang digunakan untuk pengumpulan data adalah angket dan tes dalam bentuk objektif. Setelah data- data yang dibutuhkan diperoleh maka data tersebut di olah dengan menggunakan rumus Kolerasi ganda yaitu :

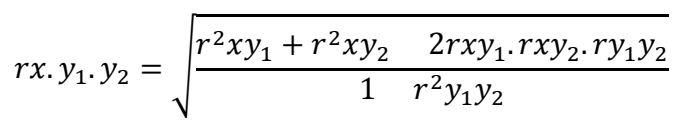

Dari hasil perhitungan yang dilakukan di atas diperoleh harga rx.y.y.y $=0,992$ Jika angka indeks korelasi tersebut dikorelasikan dengan tabel " $r$ " tabel Product Moment maka di dapat bahwa taraf signifikan 95\% atau tingkat kesalahan 5\% dengan $n=40$ diperoleh 0,312. Dengan demikian dapat diketahui bahwa nilai rx.y. $y_{2}$ hitung lebih besar daripada r tabel yakni: 0,992 $>$ 0,312. Berdasarkan konsultasi ini, maka hipotesis yang dirumuskan dalam penelitian ini dapat diterima kebenarannya. Maka dikatakan bahwa ada peningkatan minat dan prestasi belajar ekonomi peserta didik dengan menggunakan Metode Index Card Match di kelas XI SMA Negeri 1 Angkola Selatan Tahun Pelajaran 2016-2017.
\end{abstract}

Kata Kunci: Index Card Match, Prestasi Belajar, Angkola Selatan

\section{Pendahuluan}

Kualitas kehidupan bangsa sangat ditentukan oleh faktor pendidikan. Peran pendidikan sangat penting untuk menciptakan kehidupan yang cerdas, damai, terbuka dan demokratis. Oleh karena itu, pembaruan pendidikan harus selalu dilakukan untuk meningkatkan kualitas pendidikan nasional. Kemajuan suatu 
bangsa dapat dicapai melalui penataan pendidikan yang baik. Upaya peningkatan mutu pendidikan itu diharapkan dapat menaikkan harkat dan martabat manusia indonesia.

Semakin berkembangnya teknologi informasi saat ini menyebabkan berbagai perubahan terjadi diberbagai kehidupan. Perkembangan juga merambah dalam dunia pendidikan. Berdasarkan hal tersebut, maka proses pendidikan haruslah dapat dijalankan sesuai dengan ketentuan yang bersifat mendasar bagi perkembangan ilmu pengetahuan termasuk proses pembelajaran yang mendukung perubahan tersebut dan sesuai dengan tujuan kurikulum. Pembelajaran yang berkualitas adalah pembelajaran yang dilakukan secara sistematis yaitu dilakukan di sekolah. Satusatunya perbedaan antara pembelajaran yang dilakukan di sekolah dengan lingkungan lainnya adalah adanya tujuan pendidikan. Hasil belajar termasuk komponen pendidikan yang harus disesuaikan dengan tujuan pendidikan, karena hasil belajar diukur untuk mengetahui ketercapaian tujuan pendidikan melalui proses belajar mengajar. Tenaga pendidik sebagai pengajar lebih menekankan kepada tugas dalam merencanaka dan melaksanakan pengajaran. Dalam tugas ini tenaga pendidik dituntut memiliki seperangkat pengetahuan dan keterampilan teknis mengajar. Tenaga pendidik ekonomi yang utamanya harus dapat membuat pembelajaran itu lebih menarik dan dapat membuat peserta didik betah belajar ekonomi. Dan mengarahkan peserta didik untuk mampu mandiri dalam proses pembelajaran. Kata pendidikan juga berasal dari Bahasa Yunani kuno yaitu dari kata "paedogogi" kata dasarnya "Paid" yang berartikan "Anak" dan juga "Ogogos" yang artinya "Membimbing". Dari beberapa kata tersebut dapat kita simpulkan yaitu Ilmu yang mempelajari tentang seni mendidik anak.

Secara bahasa definisi Pendidikan adalah proses pengubahan sikap dan tingkah laku seseorang atau kelompok orang dalam usaha mendewasakan manusia melalui upaya pengajaran dan pelatihan yang sesuai prosedur pendidikan itu sendiri. Dalam proses pendidikan, didalamnya terdapat minat belajar akan tetapi bila hal ini tidak diperankan dengan baik oleh guru seorang peserta didik tidak akan mempunyai semangat untuk melakukan aktivitas belajar. Dalam proses belajar minat sangat diperlukan, sebab seorang yang tidak mempunyai minat belajar, tidak akan mungkin melakukan aktivitas belajar. Sehingga prestasinya pun akan meningkat.

Jika diperhatikan dan di hubungkan dengan proses belajar mengajar, khususnya bagi peserta didik, minat dalam pendidikan merupakan faktor yang penting dalam proses belajar mengajar di sekolah. Hal ini perlu di kembangkan sekaligus dibina, agar minat peserta didik tumbuh dalam suasana belajar yang aktif serta produktif. Dalam dunia pendidikan minat banyak sekali di bicarakan, terutama pengertian minat itu sendiri. Untuk lebih jelasnya di bawah ini akan di sajikan beberapa pengertian minat yang di ungkapkan oleh pakar pendidikan, Minat adalah kecenderungan yang tetap untuk memperhatikan dan mengenang beberapa kegiatan. Dari sudut emosi minat adalah perasaan ingin tahu pada suatu yang 
ada dalam dirinya dan yang di luar dirinya, jadi minat merupakan pengerahan perasaan dan menafsirkan untuk sesuatu hal. Pada sisi lain, minat adalah kecendruangan hati yang sangat tinggi terhadap sesuatu minat tidak timbul sendirian, ada unsur kebutuhan, jadi minat datangnya lebih dari dalam diri seseorang, jadi faktor internal lebih mendominasi kecendrungan tumbuhnya minat seseorang, jika dibandingkan dari faktor eksternal, minat tidak berdiri sendiri akan tetapi banyak elemen yang berperan didalamnya seperti: intelegensi, perasaan dan kekuatan mental, serta fisik.

Dalam rangka mengwujudkan belajar, maka minat berfungsi sebagai penggerak dan motivator kearah terbinanya kondisi produktif untuk mencapai tujuan dalam belajar. Menurut Usman Effendi, "Minat sangat berkaitan dengan motivasi, dimana peserta didik yang sudah termotivasi untuk belajar maka prestasinya pun akan lebih baik lagi

Prestasi tidak akan pernah dihasilkan selama seseorang tidak melakukan kegiatan Untuk mengetahui pengertian prestasi belajar secara kongkrit, Menurut M.Astrapradja bahwa: "Prestasi adalah hasil yang telah dicapai dan dilakukan maupun dikerjakan, Hal ini senada juga di temukan dalam kamus lengkap bahasa Indonesia yang menyatakan Kamisa bahwa: "Prestasi adalah hasil karya yang di capai, Setelah menelusuri uraian di atas, dapat di simpulkan mengenai makna prestasi dimana prestasi merupakan hasil yang diperoleh dari suatu aktivitas yang diperoleh berupa kesankesan yang mengakibatkan perubahan dalam diri individu, pada sisi lain prestasi belajar merupakan hasil maksimum yang dicapai oleh seseorang setelah melaksanakan usaha belajar, dengan demikian tugas guru adalah bagaimana cara meningkatkan minat seorang peserta didik sehingga prestasi peserta didik tersebut dapat meningkat atau lebih baik.

Salah satu cara yang dilakukan oleh guru untuk membangkitkan minat belajar peserta didik adalah dengan melaksanakan pembelajaran yang lebih menarik dan cocok, yang mampu meningkatkan interaksi belajar peserta didik dan memaksimalkan potensi berpikir peserta didik, maka dapat dilakukan dengan memilih metode pembelajaran yang memberikan kesempatan kepada peserta didik yang dapat meningkatkan minat dan prestasi belajar peserta didik.

Salah satu metode pembelajaran yang digunakan mampu memberikan peserta didik untuk aktif yaitu dengan menggunakan metode pembelajaran Index Card Match (Mencari Pasangan Kartu). Dimana metode ini memupuk kerjasama peserta didik di dalam menjawab pertanyaan, dengan mencocokkan kartu index yang ada di tangan mereka. Proses pembelajaran ini lebih menarik karena peserta didik mencari pasangan kartu sehingga tercipta pembelajaran yang aktif, dengan demikian minat dan prestasi peserta didik dapat di tingkatkan dan lebih baik lagi.

Berdasarkan uraian diatas, penulis tertarik untuk mengadakan penelitian dengan judul:“ Penerapan Metode Index Card Match Untuk Meningkatkan Minat Dan Prestasi Belajar Ekonomi Peserta Didik Pada Materi Pokok Akuntansi Sebagai Sistem Informasi Di Kelas XI SMA Negeri 
1 Angkola Selatan Tahun Pelajaran 2016 2017."

\section{Metode Penelitian}

Penulis menggunakan metode Index Card Match secara sistematis dan terinci berdasarkan fakta dan data yang akurat, yang diperoleh di SMA Negeri 1 Angkola Selatan. Adapun Metode yang dipergunakan sebagai berikut :

\section{Penelitian Lapangan (Field Research)}

Penelitian lapangan yaitu mengadakan penelitian secara langsung, kepada objek penelitian di lapangan yang dalam hal ini peserta didik di kelas XI IPS SMA Negeri 1 Angkola Selatan Tahun Pelajaran 2016 2017.

\section{Penelitian Kepustakaan ( Library Research )}

Penelitian kepustakaan adalah dengan mengumpulkan data - data tertulis yang bersumber dari buku - buku literaratur dan sumber - sumber tertulis sesuai dengan masalah penelitian ini.

Untuk mencapai tujuan penelitian yang telah ditetapkan, perlu disusun prosedur penelitian yang sistematis, secara umum prosedur penelitian dibagi menjadi tiga tahap yaitu: tahap persiapan, pelaksanaan, dan penyelesaian.

1. Tahap persiapan

2. Tahap pelaksanaan

3. Tahap penyelesaian

\section{Pembahasan dan Hasil}

Terdapat tiga variabel dalam penelitian ini yaitu variabel antara metode Index Card Match Meningkatkan Minat dan Prestasi Belajar Ekonomi Peserta Didik Pada Bidang Studi Ekonomi.

Penelitian dilakukan beranjak dari masalah, adapun rumusan masalah penelitian ini adalah " Apakah dengan adanya penerapan metode Index Card Matc dapat meningkatkan minat dan prestasi belajar ekonomi peserta didik Pada Materi Pokok Akuntansi Sebagai Sistem Informasi di Kelas XI SMA Negeri 1 Angkola Selatan Tahun Pelajaran 2016-2017?”.

Setelah penulis melakukan tinjauan pustaka yaitu dengan membaca buku-buku dari teori-teori yang relevan dengan variabel penelitian, maka peneliti menentukan hipotesis penelitian, yakni: "adanya peningkatan minat dan prestasi dengan menggunakan metode Index Card Match di kelas XI SMA Negeri 1 Angkola Selatan Tahun Pelajaran 2016 - 2017’.

Dari hasil perhitungan yang dilakukan diatas diperoleh harga rx.y1.y2 atau harga $r$ sebesar 0,992. Jika angka indeks korelasi tersebut dikorelasikan denga tabel " $r$ " tabel Product Moment, maka didapat bahwa taraf signifikan 95\% atau tingkat kesalahan $5 \%$ dengan $\mathrm{N}=40$ diperoleh 0,312 . Sesuai dengan pernyataan jika $r_{\text {hitung }}>\mathrm{r}_{\text {tabel }}$ maka Ha diterima kebenarannya sebaliknya jika $r_{\text {hitung }}<r_{\text {tabel }}$ maka Ha ditolak kebenarannya.

Berdasarkan ketentuan tersebut maka dapat di lihat bahwa $\mathrm{r}_{\text {hitung }}$ lebih besar dari 
$r_{\text {tabel }}$ yaitu $0,992>0,312$, maka dikatakan bahwa adanya peningkatan minat dan prestasi belajar peserta didik dengan menggunakan metode Index Card Match di kelas XI SMA Negeri 1 Angkola Selatan Tahun Pelajaran 2016 - 2017.

\section{Kesimpulan}

Dari hasil penelitian yang di peroleh maka penulis menarik kesimpulan yaitu :

1. Harga rx. $y_{1} . y_{2}$ atau harga $r$ sebesar 0,992. Jika angka indeks korelasi tersebut dikorelasikan denga tabel " $r$ " tabel Product Moment, maka didapat bahwa taraf signifikan 95\% atau tingkat kesalahan 5\% dengan $\mathrm{N}=40$ diperoleh 0,312. Sesuai dengan pernyataan jika $r_{\text {hitung }}>r_{\text {tabel }}$ maka Ha diterima kebenarannya sebaliknya jika $\mathrm{r}_{\text {hitung }}<\mathrm{r}_{\text {tabel }}$ maka Ha ditolak kebenarannya.

2. Penerapan metode Index Card Match untuk meningkatkan minat dan prestasi belajar ekonomi peserta didik pada materi pokok akuntansi sebagai sstem informasi di kelas XI SMA Negeri 1 Angkola Selatan bahwa $\mathrm{r}_{\text {hitung }}$ lebih besar dari $r_{\text {tabel }}$ yaitu $0,992>0,312$.

3. Berdasarkan ketentuan tersebut maka dapat di lihat bahwa $r_{\text {hitung lebih besar }}$ dari $r_{\text {tabel }}$ yaitu $0,992>0,312$, maka dikatakan bahwa ada peningkatan minat dan prestasi belajar peserta didik dengan menggunakan metode Index Card Match di kelas XI SMA Negeri 1 Angkola Selatan Tahun Pelajaran 2016 - 2017.

\section{Saran}

Dari kesimpulan yang dikemukakan penulis di atas, maka penulis mencoba memberikan saran-saran sebagai berikut:

1. Kepada tenaga pendidik hendaknya lebih meningkatkan cara mengajar dengan menggunakan berbagai metode pembelajaran yang dapat meningkatkan minat dan prestasi belajar peserta didik.

2. Diharapkan kepada peserta didik untuk meningkatkan minat belajarnya agar dapat mencapai prestasi yang lebih baik.

3. Kepada rekan-rekan, mengingat adanya kemungkinan kelemahan penelitian ini, maka perlu kiranya penelitian yang lebih lanjut dengan memperbesar atau memperluas objek yang diteliti.

\section{Daftar Pustaka}

Arikunto Suharsimi, 2006, Pengantar Prosedur Penelitian Suatu Pendekatan Praktek, Jakarta: Bumi Aksara

Astrapradja.M, 2005, Kamus istilah Pendidikan dan Umum, Surabaya: Usaha Nasional

Bukhari. M, 2008, Teori Minat, Jakarta: BumiAksara

Burhan, Bugin, 2009, Metodologi Kuantitatif, Jakarta: Kencana

Badan Standar Nasional Pendidikan, 2006, Standar Isi, Jakarta: Departemen Pendidikan Nasional

Djaali, 2005, Perkembangan Peserta Didik, Jakarta: Alfabeta

'Hamdani, 2009, Strategi Belajar Mengajar, Bandung: Pustaka Cipta

Hamidi, 2007, Metode Penelitian, Jakarta: Resda 
Hamzah B.Uno, 2007, Perencanaan

Pembelajaran, Jakarta: Bumi Aksara

Hisyam Zaini, 2008, Pembelajaran

Aktif, Jakarta: Aksara Timur,

Idris Shaffat, 2009, Optikized

Learning Strategy, Jakarta: Prestasi Pustaka

Isjoni, 2007, Pembelajaran Aktif,

Jakarta: AksaraTimur

M. Dalyono, 2004, Psikologi

Pendidikan, Jakarta: Rineka Cipta Mulyasa,

Noor, 2011, Metodologi Penelitian,

Jakarta: Kencana 